\title{
Sir William Turner Thiselton-Dyer, K.C.M.G., C.I.E., M.A., LL.D., F.R.S.
}

Sir William Turner Thiselton-Dyer died on 23rd December 1928. He was born in Westminster on 28th July 1843, the son of Dr W. G. Thiselton Dyer. He was educated at King's College School, and later attended King's College, London, intending to seek a career in Medicine. Altering his plans at the age of twenty, he entered Christchurch, Oxford, where he took his degree in Mathematics, and later was placed in the first class of the final school of Natural Science in the year 1867. In 1868 he became Professor of Natural History at the Royal Agricultural College, Cirencester, in 1870 Professor of Botany at the Royal College of Science, Dublin, and in 1872 Professor of Botany to the Royal Horticultural Society in London. In 1875 he was appointed to the post of Assistant Director at Kew under Sir Joseph Hooker. He held that post for ten years, and on Sir Joseph's retirement in 1885 he became Director. During the next twenty years Thiselton-Dyer as Director found a great administrative field in the development of Kew as an Imperial Botanical Centre. In this work he was conspicuously successful. A full account of his distinguished record at Kew will be found in the Kew Bulletin of Miscellaneous Information for 1929 , No. 3, pp. 65-75. Thiselton-Dyer retired from his official post at Kew on 15th December 1905 and took up residence in Gloucestershire.

Apart from his eminence as a botanist and as an administrator, Thiselton-Dyer was a keen and discriminating scholar with a wide knowledge of the classics and an acknowledged authority on the plant names which appear in the ancient writings. An appreciation of his scholarly research in this field appears in Nature, No. 3093, vol. cxxiii, 9th February 1929, p. 212.

Further details regarding Thiselton-Dyer will be found in the Journal of Botany, vol. Ixvii (1929), p. 54; in Nature, 4th August 1923, p. 182 ; Nature, 30th July 1927, p. 162. His obituary notice in the publications of the Royal Society, London, has yet to appear.

He was elected an Honorary Fellow of the Royal Society of Edinburgh in 1913.

W. W. S. 